\title{
ヒト肺組織および肝組織の残留磁化の研究
}

\author{
酒 井 英 男 ${ }^{* 1}$, 王 兵 ${ }^{* 2}$, 村 井 嘉 寛 ${ }^{* 3}$,
篮 島 \\ ${ }^{{ }_{1}}$ 富山大学理学部地球科学科 \\ *2富山医科薬科大学医学部保健医学教室 \\ *3富山医科薬科大学医学部病理学教室
}

\section{Study of Remanent Magnetization of the Human Body: Lung and Liver Tissues}

\author{
Hideo SAKAI ${ }^{* 1}$, Hongbing WANG ${ }^{* 2}$, Yoshihiro MURAI ${ }^{* 3}$, \\ Shigeru SOUKEJIMA ${ }^{* 2}$ and Sadanobu KAGAMIMORI ${ }^{* 2}$ \\ ${ }^{*}$ Department of Earth Sciences, Faculty of Science, Toyama University \\ ${ }^{* 2}$ Department of Welfare Promotion and Epidemiology, Faculty of Medicine, Toyama Medical and Pharmaceutical University \\ ${ }^{*}$ Department of Pathology, Faculty of Medicine, Toyama Medical and Pharmaceutical University
}

\begin{abstract}
In this study, we used lung and liver tissue specimens distracted from tissue to investigate remanent magnetization, and found that specimens with a volume of $6 \mathrm{~mm}^{3}$ had an intensity of $10^{-10} \mathrm{Am}^{2}$, which was significantly stronger than the noise level of the superconducting magnetometer. This finding indicates that both lung and liver tissues contain magnetic materials. We speculated that biological magnetite is the magnetic material in these tissues. In addition, we found that lung tissue specimens with strong magnetization had correspondingly strong magnetized findings in the liver tissue specimens.

In a comparison of magnetization in lung cancer tissue specimens and normal lung tissue, no significant relationship was noted, but two of the lung cancer tissue specimens showed strong magnetization. The number of lung cancer specimens studies was insufficient to investigate the relation between the magnetization (accumulation of magnetic materials) and lung cancer, and further studies are necessary.

The magnetic properties of two lung cancer tissue specimens showing strong magnetization were further investigated, and an alternating field demagnetization experiment showed that their magnetization was composed of a unit stable vector, which indicates that the lung tissue may have been magnetized after the accumulation of magnetic materials. The Wohlfarth ratio (Moskowitz et al., 1989) of them was less than 0.5, which suggests that magnetic materials are distributed in clusters in lung tissue.
\end{abstract}

Key words: remanent magnetization (残留磁化), alternating field demagnetization (交流消磁), lung tissue（肺組織）, liver tissue（肝組織), lung cancer（肺癌）

\section{1. はじめに}

1970 年代にバクテリアや蜜蜂，鮭や鳩等の様々な 生物において, 磁性を持つ酸化鉄鉣物が見つかり (Blakemore ${ }^{1)}$, Funaki et al. ${ }^{2)}$ 他)，鮭や鳩の頭部に存在する

受付 2000 年 2 月 29 日, 受理 2001 年 2 月 22 日 Reprint requests to: Hideo SAKAI

Department of Earth Sciences, Faculty of Science, Toyama University, Gofuku 3190, Toyama 930-8555, Japan

TEL: +81(76)445-6649, FAX: +81(76)445-6549

${ }^{* 4}$ 現在は京都大学大学院医学研究科社会健康医学系教室
マグネタイト $\left(\mathrm{Fe}_{3} \mathrm{O}_{4}\right)$ が回遊や帰巣本能に関係してい るとの説も提唱されている。生物の磁化を研究する手法 は, 生体組織の磁化に関する調査にも利用されるよう になった。生体磁気の研究の中心は，カリフォルニア工 科大学の Kirshvink 教授のグループであり, 主に脳を対象 として行われており，1992 年には，生物マグネタイトが 脳にも存在することが発見された（Kirshvink et al. ${ }^{3)}$ )。そ の後の研究により, 同マグネタイトは, 死後のコンタミ ネーションや化学的変化によるものではないことが明ら かになっている。また，同グループは，アルツハイマー 病の脳組織に, 強い磁性の領域が存在する傾向も示唆し 
ているが，これについては，さらに検討が必要とされる 段階にある。

生体への電磁場の影響に関する研究は, 従来, 主とし て疫学的な見地, およびMRIや脳磁場測定等により行わ れている。生体組織の磁気特性の直接的な情報も電磁波 の生体への影響を検討する際に重要であるが，実験装置 や技術上の難しさから，上述のカリフォルニア工科大学 のグループ等による幾つかの研究がある程度であり，研 究例は, まだ多くない。

自然界の岩石や堆積物には，通常数\%の鉄の酸化鉱物 (マグネタイトやへマタイト) が含まれており，これら の鉱物は残留磁化を獲得する強磁性の性質がある。その 残留磁化は数 100 年後まで残る安定性を有し, 地球磁場 の変遷の研究において重要な研究材料となっている（酒 $\left.{ }{ }^{4}\right)$ 。こうした自然界の磁性鉱物, および我々の周囲に 存在する人工的な強磁性物質は, 生体内に取り込まれて 蓄積する可能性がある。本稿では, 微細な磁性物質の調 査に有用な岩石磁気学の研究手法により, 従来, 殆ど研 究がなされていない, 肺組織と肝組織の磁気特性を調べ た結果を報告する。

\section{2. 実験方法と研究試料}

実験には，1988-1998 年に解剖され，富山医科薬科大 学の病理学教室にてホルマリン保存されていた肺と肝藏 の組織を使用した。本研究では, 1999 年の 3 月に組織か ら, 容積 $6 \mathrm{~mm}^{3}$ のポリカーボネート製容器 (約 $2 \mathrm{~cm}$ 立方 体）に収めて用意した 36 試料（表 1 , 表 3 , 表 4 に示す） について研究を実施した。試料の残留磁化（Remanent Magnetization）の測定は, 富山大学の超伝導残留磁気測 定装置 (2G Enterprise 760R) を使用して行った。同装置 による残留磁化の測定は十分な stacking を施して行われ ており，さらに磁化の信頼度のパラメータにより異常な データはチェックできる。今回の測定においては，原則 として, 1 試料の測定は 1 回行い, 測定データに異常が 認められた場合には再測定を行った。

また, 磁化特性の実験として, 超伝導磁力計付属の消 磁装置を利用した交流消磁実験, および電磁石（成瀬科 学磁気天秤 MB-2）の直流磁場を用いた人工的な等温残 留磁化（IRM: Isothermal Remanent Magnetization）の実験 を実施した。

対象とする磁性物質は僅少であり，残留磁化も微弱と 考えられる。そこで，試料の採集は，クリーンな環境に てセラミック製の道具を使って行った。また, 容器の洗 浄, 試料の運搬時のクリーンボックスの使用など, 実験 および磁化測定の際には, 塵やほこり等の影響を十分に 除く様に留意した。

臓器を用いるにあたり倫理的取り扱いに関しては, 遺 族から病理解剖のもと, 全臟器の一部を提供して頂くと の書類に従い, 担当病理医が本研究に従事した。

\section{3. 研究結果}

\section{3-1. 正常な肺組織と肝組織の磁化}

表 1 では, 11 例の検体から採取された正常組織の肺と 肝臟について, 各試料 $\left(6 \mathrm{~mm}^{3}\right)$ の残留磁化の強度を比 べている。平均の磁化強度は, 肺組織で $3.35\left(\times 10^{-10}\right.$ $\left.\mathrm{Am}^{2}\right)$, 肝組織で $1.24\left(\times 10^{-10} \mathrm{Am}^{2}\right)$ となった（表 2)。試 料保存に用いた，ホルマリン保存液を封入した試料ケー スの磁化強度は, $0.1 \sim 0.4\left(\times 10^{-10} \mathrm{Am}^{2}\right)$ であり，肺や 肝組織の磁化は，そうしたノイズより有意に強いとの結 果が得られた。また，同一検体の肺と肝組織を比べると， 肺組織の磁化の方が強かった（Wilscoxon signed-rank test では，P<0.01）。これは，肺組織に磁性物質が，より多 く含まれることを示すと考えられる。

Pearsonの相関分析により評価した肺と肝臓組織の磁 化強度の間の相関係数は, $\mathrm{r}=0.82(\mathrm{P}<0.05)$ と有意で あった。このことは, 肺の磁化強度が高い検体は肝臓の 磁化も強い傾向にあることを示しており, 組織の磁化の 強弱には，検体の個体差がある可能性を示している。

\section{3-2. 肺癌と非肺癌例の肺組織の磁化強度}

表 3 は, 肺癌 14 例について調べた肺組織の磁化強度を 示している。これを, 表 1 の非肺癌例の測定值と比較す ると, 肺癌例の肺組織には非常に強い磁化を示す 2 例の 試料が認められる。しかし, Man-Whitney rank sum test で

Table 1 Intensity of magnetization in lung and liver tissues from the 11 specimens

\begin{tabular}{cccc}
\hline \multirow{2}{*}{$\begin{array}{c}\text { Specimen } \\
\text { No. }\end{array}$} & Age & \multicolumn{2}{c}{$\begin{array}{c}\text { Intensity of magnetization } \\
\left(\times 10^{-10} \mathrm{Am}^{2}\right)\end{array}$} \\
\cline { 3 - 4 } & & Lung & Liver \\
\hline 2029 & 68 & 6.00 & 0.95 \\
2338 & 83 & 3.90 & 0.72 \\
2346 & 68 & 2.29 & 0.19 \\
2354 & 68 & 0.84 & 0.38 \\
2398 & 71 & 1.14 & 0.72 \\
2451 & 72 & 0.72 & 0.91 \\
2621 & 64 & 12.2 & 5.38 \\
2659 & 69 & 1.20 & 0.82 \\
2664 & 76 & 2.94 & 0.90 \\
2720 & 64 & 3.85 & 0.97 \\
2766 & 82 & 1.78 & 1.73 \\
\hline
\end{tabular}

Table 2 Geometric mean and standard deviation of the magnetization intensity in the lung and liver tissue and the lung cancer tissues (from Table 1 and 3)

\begin{tabular}{lccc}
\hline & & \multicolumn{2}{c}{$\begin{array}{c}\text { Intensity of magnetization } \\
\left(\times 10^{-10} \mathrm{Am}^{2}\right)\end{array}$} \\
\cline { 3 - 4 } Tissue & Numbers & Mean & SD \\
\hline Lung & 11 & 2.32 & 2.40 \\
Liver & 11 & 0.87 & 2.29 \\
Lung Cancer & 14 & 4.26 & 5.91 \\
\hline
\end{tabular}


Table 3 Intensity of magnetization of lung tissues in the $\mathbf{1 4}$ lung cancer specimens

\begin{tabular}{ccc}
\hline $\begin{array}{c}\text { Specimen } \\
\text { No. }\end{array}$ & Age & $\begin{array}{c}\text { Intensity of magnetization } \\
\left(\times 10^{-10} \mathrm{Am}^{2}\right)\end{array}$ \\
\hline 2240 & 58 & 5.36 \\
2268 & 69 & 0.54 \\
2277 & 68 & 0.38 \\
2287 & 83 & 2.91 \\
2324 & 61 & 224 \\
2333 & 64 & 0.91 \\
2349 & 76 & 1.61 \\
2362 & 76 & 2.83 \\
2411 & 75 & 2.47 \\
2434 & 72 & 19.36 \\
2613 & 73 & 10.42 \\
2632 & 82 & 1.12 \\
2670 & 64 & 8.29 \\
2693 & 64 & 47.82 \\
\hline
\end{tabular}

Table 4 Intensity of magnetization for several segments in the lung cancer tissues (2324 and 2693)

\begin{tabular}{lc}
\hline Specimen No. & $\begin{array}{c}\text { Intensity of magnetization } \\
\left(\times 10^{-10} \mathrm{Am}^{2}\right)\end{array}$ \\
\hline$<2324>$ Age61 & \\
RS10 (central) & 102.28 \\
RS10 (periphery) & 243.95 \\
RS2 & 374.84 \\
RS3 & 171.80 \\
RS8 & 0.67 \\
$<2693>$ Age 68 & \\
RS10 & 8.93 \\
RS10 (periphery) & 11.00 \\
RS2 & 14.62 \\
RS3 & 20.68 \\
RS8 & 8.79 \\
Tumor & 184.62 \\
\hline
\end{tabular}

The segment of the tumor in the lung cancer case 2693 was also studied. That in lung cancer case 2324 was not sampled.

検討したところ, 肺癌例と非肺癌例の両群の差には統計 的な有意さは見られなかった。図 1 では, 同測定值を木 ルマリン保存液や試料ケースの磁化強度と併せて示して いる。

肺癌例の, 標本番号 2324 と 2693 の 2 例の試料は, 他 の検体に比べて一桁以上強い残留磁化を持っている。標 本番号 2324 は溶鉱炉勤務の方で, 標本番号 2693 は鉄工 所勤務の方であった。

磁化の強い 2 つの肺癌例について, 肺の部位による磁 化強度の違いを調查した。表 4 に示すように, す心゙ての 部位で磁化は強い傾向にあるが，部位による違いも認め られた。また, 標本番号 2693 では, 腫瘍部 (Tumor) の 磁化を調査したところ, その磁化強度は他の部位より大 きく表れた。標本番号 2324 については，試料が採取でき ず，腫瘍部の磁化強度は検討していない。

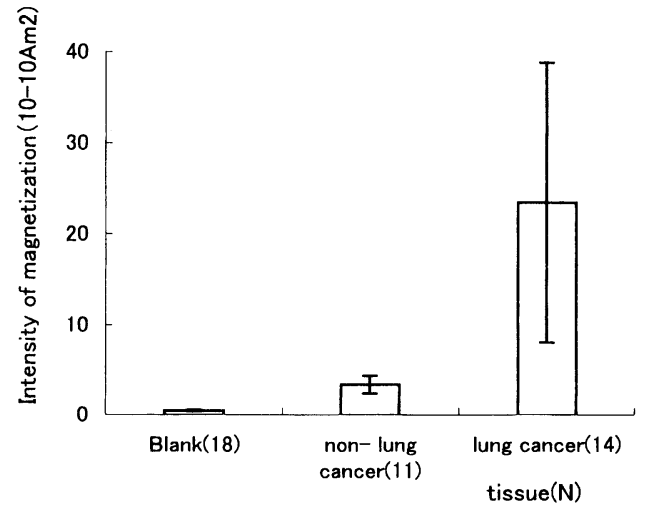

Fig. 1 Comparison of the intensity of magnetizations of lung tissue, lung cancer tissue, and the blank (specimen case with formalin). Means and standard errors are shown for each column.

\section{3-3. 磁化の強い標本番号 2324 の肺組織の磁化特性}

図 2 は, 標本番号 2324 の肺組織から得た 2 試料につい て行った交流消磁実験 (alternating field demagnetization) の結果を示している。各図で, 消磁に伴う試料の磁化方 位と強さの変化は, ザイダーベルド図法で表現されてい る $\left(\mathrm{Zijderveld}^{5)}\right)$ 。プロットは磁化ベクトルの水平面およ び鉛直面への投影であり，各プロットは，各消磁段階の 交流磁場後に測定された磁化から計算されている。消磁 前の磁化は，NRM（natural remanent magnetization）と記 している。

交流消磁に伴う磁化方位の変化に注目すると，プロッ 卜は図の原点に向かう直線上にあり，残留磁化が一成分 であることを示している。残留磁化は，試料に含まれる 磁性物質の小さな磁化の集合体なので，これは，小磁化 の方向が揃っていることを示している。

次に, 肺組織における, 磁性物質の分布特性を, Wohlfarth ratio (Moskowitz et al $\left.{ }^{6}{ }^{6}\right)$ により検討した。この 值は，走磁性バクテリアの体内におけるマグネタイト の分布を調べるために考案されたパラメータであり, 電磁石などの直流磁場で獲得される人工的な残留磁化 （IRM）の，獲得特性と消磁特性の比較により得られる。

IRM の獲得・消磁の実験は, 標本 2324 の肺組織から得 たS2,S3，S10の各 Segmentについて実施した。図 3 に, 代表例として S2 と S10 の Segment の結果を示している が，いずれの結果でも同様な特徴を示す, IRM の獲得・ 消磁曲線が得られた。両曲線の交差する磁化（初期值で 規格化）が Wohlfarth ratio であり，調査した 3 試料（S2， $\mathrm{S} 3, \mathrm{~S} 10)$ の值は全て 0.5 以下となった。0.5 以下の值は, 磁性物質が組織内でクラスターとして，かなり局在して いることを示している。

\section{4. 考察およびまとめ}

\section{4-1. 肺組織と肝組織の磁化}

肺と肝組織から採取した試料 $\left(6 \mathrm{~mm}^{3}\right)$ の残留磁化を 


\section{Zijderveld diagram (specimen 2324)}
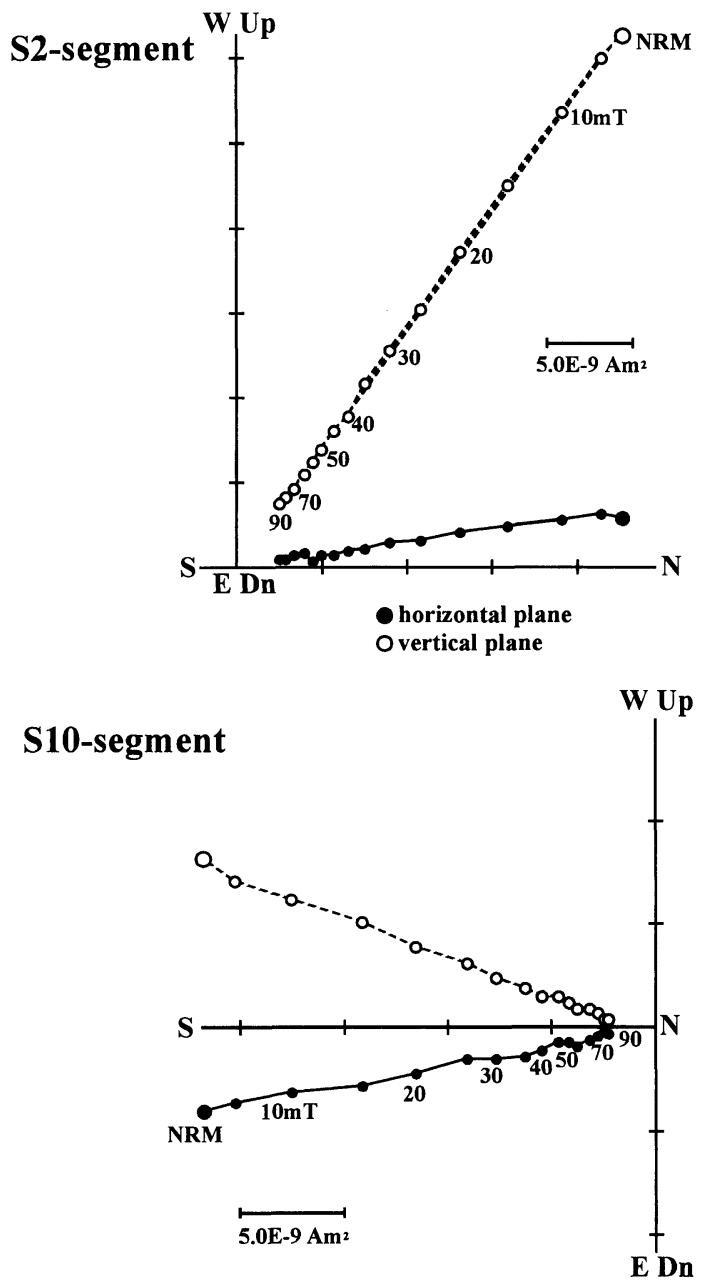

Fig. 2 Result of alternating field demagnetization on the lung tissues from the specimen 2324. Change of intensity and direction of magnetization with the progressive increasing alternating field is represented by the Zijderveld diagram.

調べた結果（表 1), 両組織には, 装置や容器のノイズレ ベルより有意に大きい $10^{-10} \mathrm{Am}^{2}$ の磁化が認められた。こ のことは，両組織に磁性物質が存在することを示してい る。また, 肺組織の方が磁化は強い傾向にあった。磁性 物質が体内（組織）に外界から入る場合，呼吸器系であ る肺組織にまず取り込まれるので，肺組織に集中し易い と考えられる。今回, 肺が肝組織より磁化が強い傾向が 得られたことは，外部環境から磁性鉱物が吸入され，体 内（組織）に蓄積されることを示していると考える。

また, 肺標本の磁化が強い個体は肝標本の磁化も強い 傾向にあり，肺に磁性物質を多く含む個体では肝組織で も磁性物質が多くなっている。こうした磁化の強弱の個 体差も, 磁性物質の体内一の蓄積に外部環境が影響して いることを示唆している。

肺組織の磁化強度について, 非肺癌例と肺癌例の両群 には統計的な有意さは見られなかったが，肺癌例には非
常に強い磁化を示す 2 例の試料が認められた。2 例は, 溶鉱炉と鉄工所勤務の方であり，粉塵として磁性物質を 吸入し易かった環境であったと考えられる。肺癌の肺組 織と磁性物質の存在の因果関係は今回, 注目した課題で あるが，試料数は十分とは言えず，さらに研究を行う必 要があると考えられる。

残留磁化が他より一析以上強い 2 例の肺癌例の肺組織 について, 部位による磁化強度の違いを検討した結果, 共通して, 肺の動きの大きい 88 の部位の磁化が弱く, 動 きの小さい $\mathrm{S} 2$ と 10 は比較的強い傾向にあった。これ は，磁性物質は肺の動きの悪い部位に蓄積され易いこ と，一方，動きの大きい部位では磁性物質は排出されや すいために蓄積量が少なくなる傾向を示していると考え られる。但し, 比較的動きが大きい S3 の磁化は強い傾 向にあり，気管や気管支の角度（向き）なども磁化強度 に影響する可能性がある。一要因で全ての分布の違いを 説明できないと考えられ，気管や気管支の影響も含め て，さらに検討が必要である。

また，一例ではあるが，磁化の強い肺癌例では，腫瘍 部は他の部位に比べて一桁強い磁化を示した。この結果 は, 肺癌に関連して, 肺腫瘍部位に磁性物質が集中寸る 機構があるのか，また，磁性物質の集中部位に肺癌が発 生した可能性を示している。

今後, 肺と肝組織について生活環境による磁化強度の 違いを検討すると共に, 他の組織の研究も進めることを 計画している。

\section{4-2. 磁化の強い肺癌例の肺組織の磁化特性}

磁化の強い標本番号 2324 の肺組織について交流消磁 特性を検討した結果, 微細な磁性物質の磁化集合と考え られる $6 \mathrm{~mm}^{3}$ バルク試料の磁化ベクトルが，一方向に 揃っていることが判明した。生体内の残留磁化は，磁性 物質が組織で生物合成される場合, 或いは体外から取り 込まれる際のいずれの場合も, 外部磁場に起因して獲得 される。一般には，地磁気が誘因磁場になると考兄ら れ，微細な磁性体はそれぞれが組織に蓄積される際に独 立な残留磁化を獲得する。つまり，標本試料に含まれる 微細な磁性体は，ランダムな小磁化の合ベクトルとして 残留磁化を形成している。この考えに依れば，磁性物質 が濃集していても，必ずしも磁化強度は比例して大きく はならない。また，蓄積に伴う磁性物質の磁化のランダ ムな集合体である組織の残留磁化は，消磁につれて不規 則に方向が変化する筈である。

標本番号 2324 の肺組織の磁化が非常に安定な単一心゙ クトルであることは，組織に含まれる微細な磁性物質の 小さな各磁化の方向が揃っていることを示している。同 様な傾向は, 標本番号 2324 の各部位および他の磁化の強 い標本でも認められた（残留磁化の弱い試料では，消磁 特性は磁力計のノイズレベルに影響されるので，検討は 難しかった)。以上の結果は, 残留磁化の強い標本は一時 期に帯磁した可能性があり，今後，この原因を検討する 


\section{Specimen (2324)}
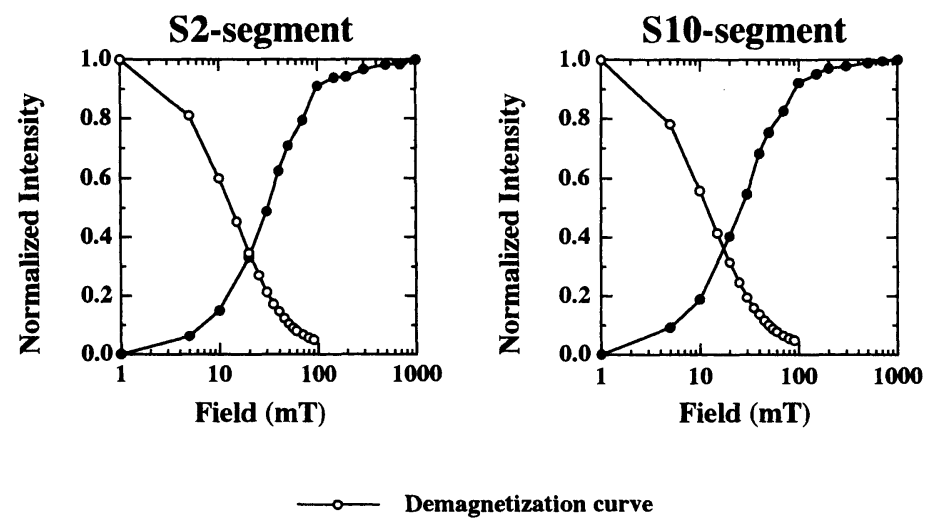

$\longrightarrow$ Acquisition curve

Fig. 3 Result of acquisition and alternating field demagnetization curves for the lung tissue in specimen 2324. Abscissa shows the change of IRM intensity as shown in the scale of normalized value by the strongest (saturated) intensity. Magnetization intensity at the intersecting point of two curves determines the Wohlfarth ratio.

必要がある。

標本に含まれる磁性物質の分布を, Wohlfarth ratioによ り検討した結果， 0.5 以下の值が得られた。同値は，磁 性物質が組織内でクラスターとして局在することを示唆 している。Schultheiss-Grassi and Dobson ${ }^{7)}$ は, 脳の組織に 認められた残留磁化について, Wohlfarth ratio を求めてお り，0.5 以下の值を報告している。この結果は, 肺や脳 に存在する磁性物質は組織内にランダムに一様に分布し てはおらず，ある領域に局在していることを示すと考え られる。脳組織と同様に, マグネタイトが肺に含まれる 磁性物質である可能性が高い。

本研究で試みた生体組織の磁化特性の調査は, 電磁場 の生体への影響の調査研究において新たな情報源となる と考えられる。磁化特性による調査手法の検討も含め て,さらに研究を進める必要がある。

\section{謝 辞}

研究において, 富山大学大学院生の野村成宏氏にお世 話になった。研究の一部に, 富山大学地域共同研究セン ター共同研究費および, 文部省科研費基盤 C（09670381） を使用した。

\section{文献}

1) Blakemore RP. Magnetotactic bacteria. Science 1975; 190: 377-379.

2) Funaki M, Sakai H, Matsunaga T, Hirose $S$. The S pole distribution on magnetic grains in pyroxenite determined by magnetotactic bacteria. Phys Earth and Planet Interi 1992; 70: 261-272.

3) Kirshvink JL, Kobayashi-Kirshvink A, Woodford BJ. Magnetite biomineralization in the human brain. Proc Acad Sci USA 1992; 89: 7683-7687.

4) 酒井英男. 岩石磁気学・古地磁気学の紹介および最近の 話題. 日本応用磁気学会誌 $1995 ; 20 ： 3-10$.

5) Zijderveld JDA. A.C. Demagnetization of rocks: analysis of result. In: Collinson DW, Creer KM, Runcorn SK, editors. Method in Palaeomagnetism. Amsterdam: Elsevier, 1967: 254-286.

6) Moskowitz BM, Frankel RB, Bazylinski DA, Jannasch HW, Lovely DR. A comparison of magnetite particles produced anaerobically by magnetotactic bacteria and dissimilatory ironreducing bacteria. Geophys Res Lett 1989; 16: 665-668.

7) Schultheiss-Grassi PP, Dobson J. Magnetic analysis of human brain tissue. BioMetals 1999; 12: 67-72. 